\title{
Profesorul CLIMENT HOREANU - în căutarea plantelor din lumea celor drepți
}

\section{F. Clinovschi}

\section{Începuturi...}

La finalul anului 2020, un an greu de uitat pentru toată omenirea, domnul Profesor Horeanu a hotărât că a venit clipa să se alăture înaintașilor noștri! Și nu conjunctural am apelat la acest cuvânt, pentru că ilustrul nostru dascăl astfel a fost întreaga sa viață: hotărât! S-a născut în anul 1941 şi, după cum îi plăcea domniei sale să spună, a copilărit într-o perioadă când selecția naturală era criteriul după care se supraviețuia, iar diferența dintre viață și moarte consta într-o doză de penicilină, doză la care nu oricine din lumea satului românesc de la acea vreme avea acces.

\section{Ambiție, putere, visuri...}

Visul copilăriei lui a fost să intre în tagma ceferiștilor, era hotărât să ajungă acolo, dar sechelele unei poliomelite infantile care și-a lăsat ,semnătura” pe gamba unui picior 1-au împiedicat să intre în lumea semi-militarizată a căilor ferate! Hotărârea sa a devenit mai înverșunată, arătând că un tânăr hudeștean (Botoșani), modest, dar ambițios și cutezător, poate să urmeze cursurile Facultăţii de Biologie-Geografie, Universitatea „Al. I. Cuza” din Iași, în dificila perioadă postbelică și să absolve cursurile universitare cu rezultate remarcabile. Atât de remarcabile încât magistrul lui, profesorul Constantin Burduja, renumit botanist și fitogeograf, îi propune o carieră de cercetare în domeniul fitocenologiei (astăzi intitulată fitosociologie, o ramură a biologiei vegetale), fără a-1 lăsa să se îndepărteze prea mult de faculta-

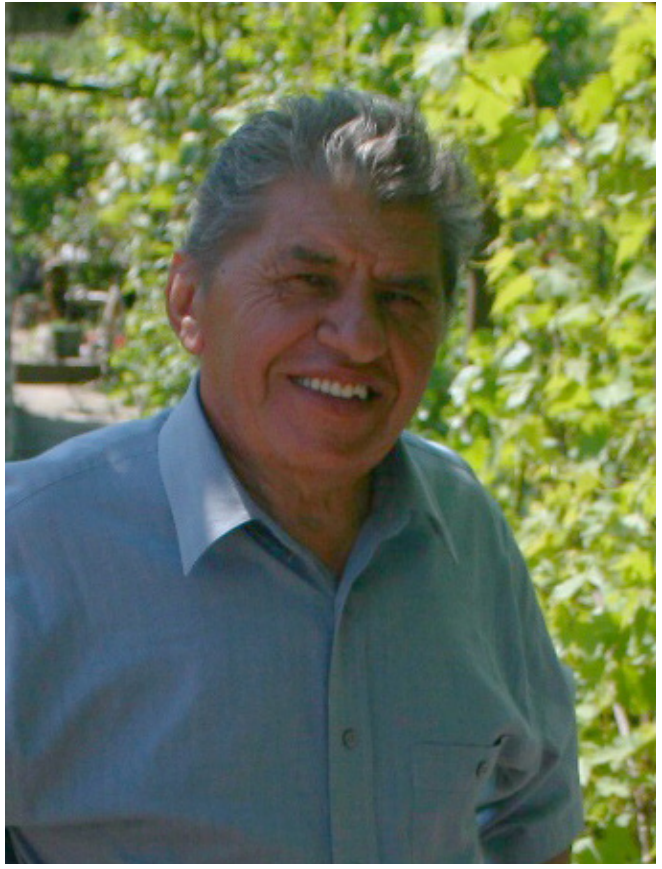

tea de pe ale cărei bănci promițătorul Climent Horeanu se ridicase ca viitor biolog de elită.

Aparent, viața tânărului Climent Horeanu părea să capete o turnură mai lină, însă încă o dată avea să i se demonstreze că nimic nu se câștigă cu ușurință: profesorul lui, Constantin Burduja, îi dictează tema tezei de doctorat, prin care trebuia să cerceteze flora și vegetaţia din stepa dobrogeană! Și iarăşi o ia de la capăt, înfruntând Necunoscutul... Și iarăşi a câștigat! Câţiva ani mai târziu, prin prisma experienței acumulate, a studiilor și cercetărilor efectuate 
și publicate, botanistul Climent Horeanu se definește ca un sistematician și fitocenolog experimentat, ajungând să identifice orice specie de plantă din zona aridă a întinderilor dobrogene, chiar și după un „,ciot uscat” (atât mai rămâne dintr-o plantă din zonele cuprinse de uscăciunea estivală, iar sintagma îi aparține!). Era momentul în care magistrul Constantin Burduja își desăvârșea tânărul discipol Climent Horeanu pentru care titlul de doctor în biologie devine o consecință pozitivă intrinsecă per ipsum!

Demonstrându-și potențialul, curajul și pasiunea pentru lumea plantelor, tânărul cercetător pune bazele unei cariere fulminante, care se caracterizează prin dârzenie, curaj, pionierat şi spirit de sacrificiu: cercetător de elită apropiat al Facultății de Biologie din Iași, inițiatorul Grădinii Botanice de la Agigea (proiect nefinalizat ca urmare a construcției Canalului Dunăre-Marea Neagră), administrator al secției Academiei Române de la Iași, iar, în final, cadru didactic și șef de catedră la Facultatea de Silvicultură din Suceava. După cum era și firesc, aceste proiecte temerare au fost treptat valorificate prin susținerea constantă și înțelegerea nemărginită a familiei sale, care se bucura de prezența domniei sale în scurtele clipe dictate de trenurile care îl purtau mereu spre noi orizonturi profesionale şi de cunoaştere.

\section{Știință și cercetare asiduă...}

După finalizarea studiilor universitare (1967), Profesorul Horeanu a activat ca botanist (19671971) la Stațiunea „Prof. I. Borcea” de la Constanța (Agigea), unde urma să realizeze "Colecția floristico-fitogeografică a Dobrogei". $\mathrm{Cu}$ mare efort a început organizarea și aducerea a numeroase specii de plante din diferite comunităţi ale Dobrogei pe terenul alocat de staţiunea de cercetări sus-amintită. Nefinalizarea acestui ambițios și valoros proiect s-a datorat trecerii acestei unități la nou-înființatul ,Institut de Cercetări Marine Constanța", pentru ca, imediat după aceea, amplasamentul alocat acestei colecții botanice să fie acoperit de apele Canalului Dunăre-Marea Neagră.

În 1971, Climent Horeanu se înscrie la doc- torat având conducător științific pe regretatul Prof. univ. dr. Constantin Burduja și este transferat pe un post de cercetător științific la Filiala Iași a Academiei - Subcomisia Monumentelor Naturii din Moldova.

În 1975 susține teza de doctorat cu titlul „Studiul florei şi vegetației Podişului Casimcea". Cercetările întreprinse anterior și cele personale au scos la iveală 1710 taxoni (1304 sp., 555 ssp., 175 var., 93 forme și 23 hibrizi) aparținând încrengăturilor Mycophyta, Lichenophyta, Bryophyta, Pteridophyta și Spermatophyta. Tabloul plantelor vasculare inventariate cuprinde 1065 sp., 54 ssp., 173 forme și 23 hibrizi. Investigațiile implicate de teză au dus la identificarea a 560 sp., 43 ssp., 140 forme și 6 hibrizi necitați din Podișul Casimcea, dintre care un număr de 14 taxoni sunt noi pentru flora Dobrogei, respectiv: Centaurea subdiffusa Prod., C. ×tauscherii A. Kern., Cetunculus minimus L., Chenopodium ambrosoides L., Isolepis setacea (L.) R.Br., Iva xanthiifolia Nutt., Lotus angustissimus L. var. brachypodus Candargy, Melica ciliata L. ssp. taurica (Hoch) Hpl., Monotropa hypopitys L., Nicandra physsaloides (L.) Gärtn., Prunella $\times$ intermedia Link., Salvia reflexa Hornen., Jurinea linearifolia D.C., Verbascum $\times$ rubiginosum W. et K. Numeroși taxoni rari, cunoscuți numai din Dobrogea, au fost semnalați în zone nemenționate. O importanță deosebită le este atribuită și taxonilor endemici (Centaurea jankae Brandza, Astragalus pseudohirsutus Nyar., Jurinea mollis (Torner) Rchb. var. dobrogensis Prod., etc.

Cercetările floristice aferente elaborării tezei de doctorat au fost publicate în 4 lucrări. Vegetaţia Podişului Casimcea cuprinde descrierea a 61 de asociații vegetale, 17 subasociații și 4 variante, dintre care 4 asociații, 9 subasociații și 4 variante sunt noi pentru știință. Despre vegetația pajiștilor xerofile din Podișul Casimcea, domnul Profesor a publicat în mod sintetic în revista Peuce - Tulcea în 1976, iar din vegetația lemnoasă doar 7 asociații au fost analizate în alt articol (Peuce 1976, p. 347-355).

De-a lungul timpului, activitatea de cercetare 
științifică desfășurată a abordat diferite domenii ale biologiei vegetale: floră, taxonomie, fitocenologie, ecologie vegetală, ocrotirea naturii.

În perioada 1976-1983, Climent Horeanu avansează ca biolog principal, ulterior fiind transferat pe aceeași funcție la Centrul de Cercetări Biologice Iași (1983-1988), ajungând cercetător principal grad II (1990).

După anul 1990, Profesorul Horeanu ia decizia de a deveni sucevean și candidează pentru postul de conferențiar universitar la Facultatea de Silvicultură din cadrul Universităţii „Ștefan cel Mare" din Suceava (concurs câștigat în septembrie 1990), pentru ca, după 1993, să obțină gradul de Profesor, titular la disciplinele Botanică, Dendrologie și Amenajarea spațiilor verzi. Pasiunea pentru plante și rigoarea academică se reflectă în binecunoscutul Laborator de Botanică-Dendrologie al facultății, dar și în cursurile de Botanică (1993) şi Dendrologie (1994) dedicate studenților.

Rezultatele cercetărilor științifice întreprinse de Profesorul Horeanu se concretizează în peste 80 studii și articole publicate în revistele din țară (Analele științifice Univ. "Al. I. Cuza" Iași, Lucrările științifice Institutul Pedagogic Galați, Constanța, Ocrotirea Naturii, Revista Română de Biologie, Studii și Comunicări Muzeului Vrancea, Suceava, Piatra Neamț etc.). De asemenea, se mai adaugă două broșuri (Rezervații naturale și monumente ale naturii din județul Vrancea, 1981, 78 p.; Rezervații naturale și monumente ale naturii din județul Vaslui, 1981, 99 p.) şi două cursuri universitare (Botanică 1993, Dendrologie 1994). Dintre cele 80 studii şi articole, la 39 Profesorul Horeanu semnează ca unic autor, la 14 prim autor, iar la 27 coautor. Cercetările de floră și vegetație abordează o gamă variată de ecosisteme, începând cu terenurile nisipoase, spațiile terasate, pajiști xerofile, vegetație ruderală și segetală, stâncării, pajiști de silvostepă, păduri de silvostepă, făgete, molidișuri, pinete, tufărişuri subalpine și alpine, pajiști montane, subalpine și alpine. Multe dintre lucrări evidențiază biodiversitatea fitogenofondului existent în rezervațiile naturale și posibilitățile de con- servare ale acestuia (Cheia - jud. Constanța; Ponoare - Bosanci, Cheile Lucavei - jud. Suceava; Ciornohal, Tudora, Vorona - jud. Botoșani; Repedea, Roșcani - jud. Iași; Bădeana jud. Vaslui; Cheile Şugăului, Munticelu - jud. Neamț; Dălhăuți, Cenaru, Scruntaru, Cheile Tișiţei, Lepșa-Zboina - jud. Vrancea).

Activitatea de cercetare a Profesorului Horeanu a vizat o serie largă de probleme, referitoare la ecosistemele forestiere, pajiști, fitogenofondul afectat de unele lucrări de hidro-ameliorații, bonitare a pajiștilor, stabilirea gradului de îmburuienire și cartarea buruienilor din terenurile agricole, studii de structură, biomasă și productivitate ale unor asociații din pădurile de limită, a tufărişurilor subalpine și alpine, a pajiștilor montane, subalpine și alpine, de biodiversitate.

Din punct de vedere fitocenologic, Profesorul Horeanu a analizat un număr mare de cenotaxoni (169), descriind 14 asociații, 18 subsociații și 10 variante noi pentru știință, dintre care unele au fost regăsite și confirmate de literatura de specialitate.

\section{Caracter, dedicare și personalitate...}

Dincolo de realizările impresionante care cântăresc greu în epopeea profesională a unui fitosociolog care poate fi considerat unul dintre primii cinci botaniști ai țării românești, merită subliniat cine a fost OMUL Climent Horeanu.

Vreme de peste două decenii Profesorul Horeanu a fost nelipsit din viața Facultăţii de Silvicultură de la Suceava, iar în primii zece ani de funcționare a acesteia, Profesorul Horeanu era de găsit în biroul său la orice oră din zi și, uneori, din noapte. A fost Profesorul pe care puteai să-l apreciezi abia după ce îl cunoșteai. A fost genul de persoană care spunea verde în față ce trebuie corectat sau eliminat, ce nu este deontologic, lipsit de bun simț sau care nu se ridică la un nivel minimal de moralitate și rigoare academică. $\mathrm{Nu}$ trebuie mult explicat că oricine ar fi fost ,,cel corectat” s-ar fi simțit cel puțin deranjat.... Cei care l-au cunoscut cu adevărat pe Profesorul Horeanu cunosc și continuarea... pentru că îmbujorarea „,apostrofatului” 
de după mustrare era doar o impresie! Odată fiind spus ce trebuia spus, Profesorul dădea dovadă că are o inimă de aur, își arăta înțelegerea, disponibilitatea și aprecia părțile bune ale celui care, cu jumătate de oră înainte, avusese parte de o ,rupere de nori” verbală și corectivă.

Tot așa se arăta și studenților! Este clar că examenul la disciplina Botanică din primul an de studiu era „cui’”! Până la examen, orice student era răscolit de un amestec de sentimente din categoria ,teamă, incertitudine....” pentru ca, după marele cui al anului I, studentul să aibă convingerea că Profesorul Horeanu este cel care poate să reprezinte interesele studențești în fața mai marilor instituției sucevene și să nu renunțe la luptă până la rezolvarea oricărei probleme care ar fi putut aduce atingere vreunui student al Facultății de Silvicultură.

Avea răbdare și tact în a explica tot ce știe despre plante, despre cum şi după ce criterii morfologice se identifică oricare specie vegetală ierboasă sau lemnoasă. Dar, ca un bun Profesor, se asigura că munca lui nu a fost în zadar, iar cel învățat trebuia să arate că efortul a fost comun, iar cunoștințele au fost temeinic însușite. Și verificarea nu era unică, pentru că orice ieșire în teren începea cu recapitularea și identificarea plantelor văzute la fața locului! Cap de listă al acestor reîmprospătări de memorie erau însăși asistenții lui, Profesorul Horeanu căutând parcă de fiecare dată confirmarea lăuntrică a faptului că nu a greșit prin alegerea acelor succesori care aveau să se ridice la nivelul așteptărilor lui.

\section{Retragere discretă, dar... Laudatio...}

După pensionare, Profesorul Climent Horeanu a mai activat câțiva ani, petrecând ore memorabile în amfiteatrele și laboratoarele Facultății de Silvicultură din Suceava. Dar, ca un dascăl înțelept, în anul 2012, a decis că a venit momentul ca magistrul să predea ștafeta discipo- lilor săi, considerând că aceștia sunt pregătiți să continue opera începută cu trudă și sacrificii în urmă cu 20 ani. A fost momentul când Profesorul Horeanu a arătat cu discreție că știe să se retragă cu demnitate, lăsând un loc gol spre care, cei care l-au cunoscut cu adevărat, se uită cu regret filial.

$\mathrm{Cu}$ toții știm că, alături de regretatul Profesor Ioan Milescu, Profesorul Horeanu a fost unul dintre temerarii școlii silvice superioare bucovinene, care a rânduit bunul mers al facultății noastre și care s-a luptat din răsputeri ca această școală să dăinuie peste timp. Astăzi, cu mândrie putem să spunem fără tăgadă că eforturile temerarilor şi-au arătat roadele!

Fără a epata, Profesorul Climent Horeanu a demonstrat că perseverența, seriozitatea și munca asiduă reprezintă pietre de temelie pentru a deveni reper social și profesional, un exemplu demn de urmat. Domnia sa și-a lăsat amprenta în personalitatea oamenilor apropiați și va rămâne unul dintre colegii noștri de suflet, a cărui absență o vom simți cu toții, în mod deosebit cei care am crescut și ne-am format în preajmă-i.

Drum lin către veșnicie, Domnule Profesor!

\section{Abstract. Professor CLIMENT HOREANU - in search of plants from the afterlife}

This article aims to give a brief overview of the professional itinerary and scientific life of former Professor Climent Horeanu, a renowned botanist and scientist who devoted much of his life to elite research and the guidance of students and disciples who mourn his passing. Strong personality and formidable researcher, Professor Climent Horeanu constitutes a benchmark for all generations of students and researchers in love with nature and concerned about its proper functioning for our future, for all of us.

Author. Florin Clinovschi - Ștefan cel Mare University of Suceava, Faculty of Forestry, 13 Universității, 720229 Suceava, Romania. 